\title{
FAKTOR FAKTOR YANG MEMPENGARUHI KEPATUHAN IBU MEMBAWA BALITA KE POSYANDU DANAU INDAH PUNGGUR I DI WILAYAH KERJA PUSKESMAS KABIL
}

\author{
Deviana \\ Program Studi Ilmu Keperawatan, STIKes Awal Bros Batam \\ Email : devikesdam80@gmail.com
}

\begin{abstract}
ABSTRAK
Kelurahan Kabil merupakan salah satu bagian dari Kota batam yang mempunyai Posyandu sebanyak 16 Posyandu. Posyandu Danau Indah Punggur 1 (DIP 1) dipilih menjadi tempat penelitian karena jumlah kunjungan balitanya rendah. Melalui wawancara pada ibu yang mempunyai anak balita dan tinggal diwilayah Posyandu DIP, Ibu mengatakan kegiatan Posyandu sama saja setiap bulannya. anaknya sudah mendapat imunisasi dasar lengkap, berat badan anaknya juga selalu baik setiap bulannya sehingga ibu membawa anaknya ke Posyandu kalau ada waktu saja. Penelitian ini bertujuan untuk mengetahui faktor faktor yang mempengaruhi kepatuhan ibu untuk datang ke Posyandu Danau Indah Punggur 1 di wilayah kerja Puskesmas Kabil Kota Batam Tahun 2019 pada Juni 2020. Rancangan penelitian ini adalah deskriptif kuantitatif dengan pendekatan cross sectional dengan metode pengambilan sampel dalam penelitian ini adalah total sampling. Sampel dalam penelitian ini terdiri dari ibu yang mempunyai balita usia 12 - 59 bulan yang berjumlah 30 responden yang berdomisili di wilayah binaan Posyandu Danau Indah Punggur 1 di wilayah Puskesmas Kabil kecamatan Nongsa dan data dianalisa menggunakan uji chi-square. Hasil diketahui bahwa ada hubungan antara tingkat pengetahuan, sikap dan dukungan keluarga dengan kepatuhan ibu membawa balita ke Posyandu Danau Indah Punggur 1 tahun 2020 Bagi puskesmas diharapkan menciptakan inovasi baru sehingga kegiatan Posyandu lebih menarik minat ibu untuk datang ke Posyandu seperti memberikan penghargaan seperti sertifikat kepada ibu yang patuh membawa balita ke Posyandu. Selain itu Puskesmas melibatkan lintas sektor dalam promosi kesehatan sehingga mampu meningkatkan perhatian masyarakat terhadap kegiatan Posyandu
\end{abstract}

Kata kunci : Kepatuhan Ibu, Tingkat Pengetahuan, Sikap, Dukungan Keluarga 


\title{
Factors Affecting Mother Compliance Bringing Toddlers To Posyandu Danau Indah Punggur I In The Work Area Of Kabi Health Center
}

\begin{abstract}
Kabil Village is one part of Batam City which has 16 Posyandu. Lake Indah Punggur 1 Posyandu (DIP 1) was chosen as a research site because of the low number of toddler visits. Through interviews with mothers who have children under five and living in the Posyandu DIP, Ibu said that Posyandu activities are the same every month. his child has received complete basic immunization, his child's weight is always good every month so the mother takes her child to the Posyandu if there is only time. This study aims to determine the factors that influence maternal compliance to come to Posyandu Danau Indah Punggur 1 in the working area of Batam City Kabil Health Center in 2019 in June 2020. The design of this study is quantitative descriptive with cross sectional approach with the sampling method in this study is total sampling. The sample in this study consisted of mothers of children aged 12 - 59 months, totaling 30 respondents who were domiciled in the Posyandu Danau Danau Punggur 1 area in the Kabil Health Center area of Nongsa sub-district and the data were analyzed using the chi-square test. The results revealed that there is a relationship between the level of knowledge, attitude and family support with the mother's compliance in bringing toddlers to Posyandu Danau Indah Punggur 1 2020. Puskesmas are expected to create new innovations so that Posyandu activities attract more mothers to come to Posyandu such as giving awards such as certificates to mothers who obediently brings toddlers to Posyandu. In addition, Puskesmas involve cross-sectors in health promotion so as to increase public attention towards Posyandu activities
\end{abstract}

Keywords: Mother Compliance, Knowledge Level, Attitude, Family Support Bibliography : 28 (2015-2018) 


\section{PENDAHULUAN}

Posyandu merupakan salah satu fasilitas kesehatan yang sangat diperlukan untuk mendekatkan upaya preventif dan promotif dalam upaya memelihara dan meningkatkan kesehatan balita. Keterlambatan pertumbuhan dan perkembangan balita, dapat terdeteksi melalui penimbangan balita setiap bulannya dengan pengawasan dari petugas kesehatan (Kementrian Kesehatan RI, 2014).

Manfaat kegiatan Posyandu diantaranya adalah mendukung perbaikan perilaku keluarga dan keadaan gizi balita melalui partisipasi keluarga untuk membawa balita setiap bulan ke Posyandu. Kegiatan yang dilakukan di posyandu diantaranya adalah penimbangan berat badan, pengukuran tinggi badan, pemberian imunisasi dasar dan pemberian vitamin A dua kali setahun untuk balita usia 6 bulan sampai 59 bulan. Penyuluhan kesehatan serta konsultasi gizi juga merupakan kegiatan yang dilakukan di Posyandu yang bermanfaat untuk meningkatkan pengetahuan ibu dalam meningkatkan pertumbuhan dan perkembangan anak. Diadakannya Posyandu setiap bulan dapat membantu pemantauan pertumbuhan dan perkembangan kesehatan balita setempat sehingga dapat mencegah sedini mungkin terjadinya gizi kurang atau buruk, balita akan terlindung dari penyakit yang dapat dicegah dengan imunisasi dan pemberian vitamin A sehingga akan menurunkan angka kesakitan dan kematian Balita (Susilowati, 2017).

Menurut penelitian Altum yang ditulis kembali dalam penelitian Noeralim, dkk pencapaian cakupan ini akan menggambarkan semakin banyak masyarakat yang mengetahui manfaat kegiatan Posyandu dan semakin banyak balita yang akan terpantau pertumbuhan dan perkembangannya bahkan dalam jangka panjang akan mengurangi angka gizi kurang dan gizi buruk serta menurunkan angka kematian balita (Noeralim, Laenggeng, 2016).

Kelurahan Kabil merupakan salah satu bagian dari Kota batam yang mempunyai Posyandu sebanyak 16 Posyandu. Posyandu Danau Indah Punggur 1 ( DIP 1 ) dipilih menjadi tempat penelitian karena jumlah kunjungan balitanya rendah. DIP 1 mempunyai cakupan penimbangan di 3 Rukun Warga (RW) dan 11 Rukun Tetangga (RT) dengan sasaran balita sebanyak 180 anak. Berdasarkan buku register kunjungan kader Posyandu tiap bulannya, rata rata kunjungna sebanyak 50 balita atau sekitar $27,7 \%$ dari jumlah sasarannya. Rendahnya angka kunjungan ini dapat menunjukkan kurangnya keinginan masyarakat khususnya ibu untuk mengikuti kegiatan Posyandu.

Hasil studi pendahuluan yang peneliti lakukan di Posyandu DIP 1 didapatkan melalui wawancara pada ibu yang mempunyai anak balita dan tinggal diwilayah Posyandu DIP 1. Wawancara yang dilakukan mengacu pada kuesioner yang peneliti desain untuk mengetahui faktor faktor kepatuhan ibu membawa balita ke Posyandu. Dari 10 ibu yang diwawancarai 5 orang Ibu mengatakan tidak datang ke Posyandu karena anaknya sudah mendapat imunisasi dasar lengkap sehingga tidak perlu ditimbang lagi setiap bulannya. Ibu tidak mengetahui sampai umur berapa anaknya ditimbang ke Posyandu. 1 orang ibu mengatakan suaminya tidak mengijinkan ke Posyandu dengan alasan akan merepotkan ibu dan harus menunggu antrian yang lama 
karena banyak yang mau menimbang. 4 orang ibu yang peneliti wawancarai juga mengatakan Posyandu itu sama saja kegiatannya setiap bulan, kalau sudah lengkap imunisasi dasar tidak perlu repot repot ke Posyandu hanya untuk menimbang. Anaknya pun juga dalam keadaan sehat dan tidak ada keluhan.

Faktor lain yang peneliti temukan saat wawancara adalah sikap ibu terhadap Posyandu . Ibu mengatakan kegiatan Posyandu sama saja setiap bulannya. anaknya sudah mendapat imunisasi dasar lengkap, berat badan anaknya juga selalu baik setiap bulannya sehingga ibu membawa anaknya ke Posyandu kalau ada waktu saja.

Dari uraian diatas peneliti tertarik untuk melakukan penelitian dengan judul " Faktor faktor yang mempengaruhi ibu untuk membawa balita ke Posyandu Danau Indah Punggur 1 di wilayah kerja Puskesmas Kabil Kota Batam Tahun 2020 “.

\section{METODELOGI PENELITIAN}

Jenis penelitian yang digunakan pada penelitian ini adalah deskriptif kuantitatif dengan pendekatan cross sectional. Penelitian ini bertujuan untuk menganalisa faktor faktor yang mempengaruhi ibu untuk membawa balita ke Posyandu Danau Indah Punggur 1 di wilayah kerja Puskesmas Kabil Kota Batam. Pada penelitian ini sebagai populasinya adalah ibu yang mempunyai balita usia 12 59 bulan yang berjumlah 30 responden. Pada penelitian ini, peneliti menggunakan teknik sampel jenuh atau total sampling yaitu teknik penentuan sampel dengan cara mengambil seluruh anggota populasi sebagai responden atau sampel yaitu 30 orang.

\section{HASIL PENELITIAN}

Berdasarkan hasil penelitian, diperoleh karakteristik responden yang meliputi usia ibu, usia anak, jumlah anak, pendidikan ibu dan pekerjaan ibu dapat dilihat pada tabel dibawah ini:

\section{Karakteristik Responden}

Tabel 4.1 Karakteristik Responden Berdasarkan Usia Ibu, Usia Anak, Jumlah Anak, Pendidikan Ibu dan Pekerjaan Ibu di Wilayah Posyandu Danau Indah Punggur 1 Tahun 2020

\begin{tabular}{clcc}
\hline NO & \multicolumn{1}{c}{$\begin{array}{c}\text { Karakteristik } \\
\text { Responden }\end{array}$} & f & \% \\
\hline 1 & Usia Ibu & 17 & 56,7 \\
& a. 20-35 Tahun & 9 & 30,0 \\
& b. 31-45 Tahun & 4 & 13,3 \\
& c. >46Tahun & $\mathbf{3 0}$ & $\mathbf{1 0 0}$ \\
& $\quad$ Total & & \\
2 & Usia Anak & 12 & 40,0 \\
& a. 12-24Bulan & 11 & 36,7 \\
& b. 25-36 Bulan & 6 & 20,0
\end{tabular}


d. 49-59 Bulan

Total

3 Jumlah Anak

a. 1

b. $>2$

Total

4 Pendidikan

a. Tidak tamat SD $\quad 1 \quad 3,3$

b. Tamat SD

c. Tamat SLTP

d. Tamat SLTA/SMA/MA

e. Tamat Diploma/PT Total

5 Pekerjaan

$\begin{array}{llcc}\text { a. Pegawai Negeri } & 0 & 0 \\ & \text { Sipil (PNS) } & 0 & 0 \\ \text { b. } & \text { Swasta } & 3 & 10,0 \\ \text { c. Wiraswasta } & 24 & 80,0 \\ \text { d. } & \text { Ibu Rumah Tangga } & 3 & 10,0 \\ \text { e. Lain-lain } & \mathbf{3 0} & \mathbf{1 0 0} \\ & \text { Total } & & \end{array}$

Berdasarkan tabel 4.1 di atas dapat dilihat bahwa responden yang dibagikan kuesioner sebanyak 30 orang. Usia responden terbesar adalah yang berusia 201-35 tahun sebanyak 17 orang $(56,7 \%)$. Dengan usia anak responden terbesar adalah usia 12-24 bulan dengan jumlah 12 orang (40,0\%) dan jumlah anak terbesar adalah lebih dari 2 dengan jumlah 22 orang (73,3\%). Dalam penelitian ini, pendidikan responden terbesar adalah SLTA/SMA/MA sebanyak 14 orang $(46,7 \%)$. Sedangkan berdasarkan pekerjaan adalah ibu rumah tangga sebanyak 24 orang $(80,0 \%)$.

ANALISA UNIVARIAT

Tabel 4.2 Distribusi Frekuensi Kepatuhan Responden di Wilayah Posyandu Danau Indah Punggur 1 Tahun 2020

\begin{tabular}{llc|c} 
No & Kepatuhan & f & \% \\
\hline 1 & Patuh & 22 & 73,3 \\
\hline 2 & Tidak Patuh & 8 & 26,7 \\
\hline & Jumlah & $\mathbf{3 0}$ & $\mathbf{1 0 0}$ \\
\hline
\end{tabular}

Berdasarkan Tabel 4.2. diatas dapat dilihat bahwa kepatuhan responden di Wilayah Posyandu Danau Indah Punggur 1 Tahun 2020 yaitu kategori patuh sebanyak 22 orang $(73,3 \%)$ dan yang tidak patuh sebanyak 8 orang $(26,7 \%)$.

Tabel 4.3 Distribusi Frekuensi Tingkat Pengetahuan Responden di Wilayah Posyandu Danau Indah Punggur 1 Tahun 2020

\begin{tabular}{ccc|c} 
No & Sikap & f & $\%$ \\
\hline 1 & Positif & 15 & 50,0 \\
\hline
\end{tabular}




\begin{tabular}{rrr|r}
\hline 2 & Negatif & 15 & 50,0 \\
\hline Jumlah & $\mathbf{3 0}$ & $\mathbf{1 0 0}$ \\
\hline
\end{tabular}

Berdasarkan Tabel 4.4. diatas dapat dilihat bahwa sikap responden di Wilayah Posyandu Danau Indah Punggur 1 Tahun 2020 yaitu positif sebanyak 15 orang $(50,0 \%)$ dan negatif sebanyak 15 orang $(50,0 \%)$.

Tabel 4.5 Distribusi Frekuensi Dukungan Keluarga Responden di Wilayah Posyandu Danau Indah Punggur 1 Tahun 2020

\begin{tabular}{ccc|c} 
No & Sikap & f & \% \\
\hline 1 & Mendukung & 10 & 33,3 \\
\hline 2 & Tidak mendukung & 20 & 66,7 \\
\hline & Jumlah & $\mathbf{3 0}$ & $\mathbf{1 0 0}$ \\
\hline
\end{tabular}

Berdasarkan Tabel 4.5. diatas dapat dilihat bahwa dukungan keluarga responden di Wilayah Posyandu Danau Indah Punggur 1 Tahun 2020 terbesar yaitu tidak mendukung sebanyak 20 orang $(66,7 \%)$ dan terkecil yaitu tidak mendukung sebanyak 10 orang $(33,3 \%)$.

\section{Analisis Bivariat}

Faktor faktor yang mempengaruhi ibu untuk membawa balita ke Posyandu Danau Indah Punggur 1 di wilayah kerja Puskesmas Kabil Kota Batam dapat dilihat pada tabel dibawah ini:

Tabel 4.6 Hubungan Tingkat Pengetahuan Dengan Kepatuhan Responden Membawa Balita Ke Posyandu di Wilayah Posyandu Danau Indah Punggur 1

Tahun 2020

\begin{tabular}{llcccccccc}
\hline No & Tingkat & \multicolumn{4}{c}{ Kepatuhan } & Jumlah & Nilai \\
\cline { 3 - 7 } & Pengetahuan & \multicolumn{2}{c}{ Patuh } & \multicolumn{3}{c}{ Tidak Patuh } & & & p value \\
& & $\mathrm{n}$ & $\%$ & $\mathrm{n}$ & $\%$ & $\mathrm{n}$ & $\%$ & \\
\hline 1. & Baik & 16 & 72,7 & 0 & 0 & 16 & 53,3 & 0.000 \\
2 & Cukup & 5 & 22,7 & 1 & 12,5 & 6 & 20,0 & \\
\hline 3 & Kurang & 1 & 4,5 & 7 & 87,5 & 8 & 26,7 & \\
\hline & Jumlah & 22 & 29,4 & 8 & 70,5 & 30 & 100 &
\end{tabular}

Berdasarkan tabel 4.6 dapat diketahui bahwa dari 30 responden sebagian besar responden tingkat pengetahuan baik dengan patuh membawa balita ke posyandu ada $72,7 \%$, hanya $0 \%$ yang tidak patuh dan sebagian besar tingkat pengetahuan responden kurang dengan tidak patuh membawa balita ke posyandu ada 87,5\%, hanya $4,5 \%$ yang patuh. Hasil uji statistik chi-square didapatkan nilai pvalue $0,000 \leq 0,05$ berarti dapat disimpulkan artinya Ho ditolak dan Ha diterima (ada hubungan antara tingkat pengetahuan dengan kepatuhan ibu membawa balita ke Posyandu Danau Indah Punggur 1 tahun 2020).

Tabel 4.7 Hubungan Sikap Dengan Kepatuhan Responden Membawa Balita Ke Posyandu di Wilayah Posyandu Danau Indah Punggur 1 Tahun 2020

\begin{tabular}{ccccccccc}
\hline No & \multicolumn{4}{c}{ Kepatuhan } & & Jumlah & Nilai \\
& & \multicolumn{2}{c}{ Patuh } & \multicolumn{2}{c}{ Tidak Patuh nn } & & & p value \\
& & $n$ & $\%$ & $n$ & $\%$ & $n$ & $\%$ & \\
\hline
\end{tabular}




\begin{tabular}{llccccccc}
\hline 1. & Positif & 15 & 68,2 & 0 & 0 & 15 & 50 & 0.002 \\
2. & Negatif & 7 & 31,8 & 8 & 100 & 15 & 50 & \\
\hline & Jumlah & 22 & 73,3 & 8 & 26,7 & 30 & 100 &
\end{tabular}

Berdasarkan tabel 4.7 dapat diketahui bahwa dari 30 responden sebagian besar responden sikap positif dengan patuh membawa balita ke posyandu ada $68,2 \%$, hanya $0 \%$ yang tidak patuh dan sebagian besar sikap responden negatif dengan tidak patuh membawa balita ke posyandu ada $100 \%$, hanya $31,8 \%$ yang patuh. Hasil uji statistik chi-square didapatkan nilai pvalue $0,002 \leq 0,05$ berarti dapat disimpulkan artinya Ho ditolak dan Ha diterima (ada hubungan antara sikap dengan kepatuhan ibu membawa balita ke Posyandu Danau Indah Punggur 1 tahun 2020)

Tabel 4.8 Hubungan Dukungan Keluarga Dengan Kepatuhan Responden Membawa Balita Ke Posyandu di Wilayah Posyandu Danau Indah Punggur 1 Tahun 2020

\begin{tabular}{|c|c|c|c|c|c|c|c|c|}
\hline \multirow[t]{3}{*}{ No } & \multirow{3}{*}{$\begin{array}{r}\text { Dukungan } \\
\text { Keluarga }\end{array}$} & \multicolumn{4}{|c|}{ Kepatuhan } & \multicolumn{2}{|c|}{ Jumlah } & \multirow{3}{*}{$\begin{array}{l}\text { Nilai } \\
\text { p value }\end{array}$} \\
\hline & & \multicolumn{2}{|c|}{ Patuh } & \multicolumn{2}{|c|}{$\begin{array}{c}\text { Tidak } \\
\text { Patuh }\end{array}$} & \multirow[b]{2}{*}{$\mathrm{n}$} & \multirow[b]{2}{*}{$\%$} & \\
\hline & & $\mathrm{n}$ & $\%$ & $\mathrm{n}$ & $\%$ & & & \\
\hline 1. & Mendukung & 10 & 45,5 & 0 & 0 & 10 & 33,3 & 0.029 \\
\hline 2. & $\begin{array}{l}\text { Tidak } \\
\text { mendukung }\end{array}$ & 12 & 54,5 & 8 & 100 & 20 & 66,7 & \\
\hline & Jumlah & 22 & 73,3 & 8 & 26,7 & 30 & 100 & \\
\hline
\end{tabular}

Berdasarkan tabel 4.8 dapat diketahui bahwa dari 30 responden sebagian besar responden keluarga mendukung dengan patuh membawa balita ke posyandu ada $45,5 \%$, hanya $0 \%$ yang tidak patuh dan sebagian besar keluarga tidak mendukung dengan tidak patuh membawa balita ke posyandu ada $100 \%$, hanya $54,5 \%$ yang patuh. Hasil uji statistik chi-square didapatkan nilai pvalue $0,029 \leq 0,05$ berarti dapat disimpulkan artinya Ho ditolak dan Ha diterima (ada hubungan antara dukungan keluarga dengan kepatuhan ibu membawa balita ke Posyandu Danau Indah Punggur 1 tahun 2020)

\section{PEMBAHASAN}

\section{a. Hubungan antara tingkat pengetahuan tentang Posyandu dengan kepatuhan ibu membawa balita ke Posyandu}

Berdasarkan hasil uji statistic chi-square didapatkan nilai pvalue $0,000 \leq 0,05$ berarti dapat disimpulkan artinya Ho ditolak dan Ha diterima (ada hubungan antara tingkat pengetahuan dengan kepatuhan ibu membawa balita ke Posyandu Danau Indah Punggur 1 tahun 2019). Analisis keeratan hubungan dua variabel didapat $\mathrm{OR}=21,264$.

Secara keseluruhan hasil penelitian menunjukkan bahwa responden di Posyandu Danau Indah Punggur memiliki tingkat pengetahuan yang baik dan tingkat kepatuhan ibu membawa Balita ke Posyandu juga tinggi. Hal ini berarti pengetahuan mempengaruhi kepatuhan ibu membawa balita ke Posyandu. Tingkat pengetahuan yang baik akam mempengaruhi kepatuhan ibu membawa Balita untuk mengikuti kegiatan Posyandu setiap bulan. Pengetahuan adalah hasil dari tahu yang terjadi setelah orang melakukan penginderaan terhadap suatu obyek tertentu. 
Pengetahuan atau kognitif merupakan faktor yang sangat penting untuk terbentuknya tindakan seseorang (Notoadmodjo, 2016).

Pada penelitian ini menunjukkan adanya pengaruh antara tingkat pengetahuan yang tinggi dengan kepatuhan ibu membawa Balita ke Posyandu setiap bulannya. Hal ini sejalan dengan penelitian yang dilakukan oleh Ardiani (2017) tentang hubungan pengetahuan dan motivasi ibu yang mempunyai Balita terhadap kunjungan Posyandu di wilayah kerja Puskesmas Rasimah Ahmad Bukittinggi berdasarkan pengujian statistik diperoleh nilai $\mathrm{p}$ value $=0,000(\mathrm{p}<\alpha)$, yang dapat disimpulkan adanya hubungan pengetahuan ibu balita dengan kunjungan posyandu di Posyandu III Wilayah Kerja Puskesmas Rasimah Ahmad Kota Bukittinggi.

\section{b. Hubungan antara sikap dengan kepatuhan ibu membawa balita ke Posyandu}

Hasil uji statistik chi-square didapatkan nilai pvalue $0,002 \leq 0,05$ berarti dapat disimpulkan artinya Ho ditolak dan Ha diterima (ada hubungan antara sikap dengan kepatuhan ibu membawa balita ke Posyandu Danau Indah Punggur 1 tahun 2020). Analisis keeratan hubungan dua variabel didapat $\mathrm{OR}=2,143$.

Hasil penelitian menunjukkan bahwa responden di Posyandu Danau Indah Punggur 1 memiliki sikap yang positif terhadap kegiatan Posyandu, dimana sikap yang positif ini mempengaruhi tingkat kepatuhan ibu untuk membawa Balita ke Posyandu. Hal ini sesuai dengan teori Koentjaraningrat dalam Busri (2017) yang mengemukakan bahwa sikap dapat menimbulkan pola-pola cara berfikir tertentu dalam masyarakat dan sebaliknya, pola-pola cara berfikir ini mempengaruhi tindakan dan kelakuan masyarakat, baik dalam kehidupan sehari-hari maupun dalam hal membuat keputusan yang penting dalam hidup.

Selain itu adanya keyakinan dari ibu bahwa akan banyak manfaat yang didapat pada kegiatan Posyandu yang bisa ibu dapatkan dengan mudah, dekat dan tidak memerlukan biaya yang besar untuk memantau pertumbuhan dan perkembangan anak balita. Menurut Theory of Reasoned Action Fishbein dan Ajzen dalam penelitian Sahat (2015) menempatkan sikap pada posisi yang sentral dalam kaitannya dengan tindakan manusia. Sikap terbentuk sebagai hasil dari adanya keyakinan. Individu yang yakin tindakan yang ditimbulkan berdampak positif serta adanya dukungan dari lingkungan sekitarnya maka akan ada kecenderungan untuk melakukan tindakan tersebut. Demikian sebaliknya jika individu yakin apa yang akan dilakukannya berdampak negatif maka akan bersikap menolak melakukan tindakan tersebut (Simbolon, 2015).

\section{c. Hubungan antara dukungan keluarga, suami terhadap keptuhan ibu membawa balita ke posyandu}

Hasil uji statistik chi-square didapatkan nilai pvalue $0,029 \leq 0,05$ berarti dapat disimpulkan artinya Ho ditolak dan Ha diterima (ada hubungan antara dukungan keluarga dengan kepatuhan ibu membawa balita ke Posyandu Danau Indah Punggur 1 tahun 2020). Analisis keeratan hubungan dua variabel didapat $\mathrm{OR}=1,667$.

Secara keseluruhan jumlah responden di Posyandu Danau Indah Punggur 1 yang tidak mendapat dukungan dari keluarga lebih banyak dibanding yang mendapat dukungan dari keluarga. Hal ini mempengaruhi tingkat kepatuhan ibu untuk datang 
membawa balita ke Posyandu. Menurut Notoatmodjo dalam penelitian Rahmatika (2016) faktor penguat untuk seseorang berperilaku sehat salah satunya adalah adanya dukungan dari keluarga yang berupa tindakan, sikap dan penerimaan keluarga terhadap kepatuhan ibu membawa balita ke Posyandu dan selalu siap memberikan pertolongan dan bantuan jika diperlukan. Ibu balita yang mendapat dukungan dari keluarganya cenderung lebih aktif dalam melakukan penimbangan balita ke Posyandu.

Sama halnya dengan penelitian yang dilakukan oleh Ferry Wandikbo (2017) dimana hasil penelitian responden menunjukkan bahwa sebagian besar keluarga tidak mendukung karena skor mempunyai nilai < mean T (50). Kurangnya dukungan tersebut ditunjukkan oleh hasil kuesioner yang sebagian besar menjawab tidak memberikan informasi tentang jadwal buka posyandu ketika orang tua akan membawa balita untuk diberikan imunisasi dan enggan mendengarkan dengan seksama ketika orang tua mengeluh tentang imuninsasi yang diberikan kepada anaknya.

Peneliti berasumsi tidak adanya dukungan keluarga dikarenakan banyak faktor, seperti kesibukan suami yang bekerja pada hari dilaksanakannya kegiatan Posyandu sehingga tidak bisa menemani ibu ke Posyandu dan menyerahkan sepenuhnya keputusan kepada ibu untuk mengikuti kegiatan Posyandu atau tidak. Selain itu keluarga tidak menanyakan informasi dari ibu tentang kegiatan Posyandu yang diikuti sehingga ibu merasa keluarga tidak memperhatikan apakah ibu rutin mengikuti kegiatan Posyandu atau tidak.

\section{KESIMPULAN DAN SARAN KESIMPULAN}

1. Gambaran tingkat pengetahuan responden pada penelitian ini adalah yang memiliki pengetahuan baik sebanyak 16 responden ( 53,3\%).

2. Gambaran sikap responden pada penelitian ini adalah sikap ibu yang positif terhadap Posyandu sebanyak 15 responden ( $50 \%$ ).

3. Gambaran dukungan keluarga responden pada penelitian ini adalah tidak ada dukungan keluarga sebanyak 20 responden ( 66,7 \%).

4. Gambaran tingkat kepatuhan pada penelitian ini adalah patuh sebesar 73,3\%.

5. Hasil uji statistik chi-square didapatkan nilai pvalue $0,000 \leq 0,05$ berarti dapat disimpulkan artinya Ho ditolak dan Ha diterima (ada hubungan antara tingkat pengetahuan dengan kepatuhan ibu membawa balita ke Posyandu Danau Indah Punggur 1 tahun 2020). Analisis keeratan hubungan dua variabel didapat $\mathrm{OR}=21,264$.

6. Hasil uji statistik chi-square didapatkan nilai pvalue $0,002 \leq 0,05$ berarti dapat disimpulkan artinya Ho ditolak dan Ha diterima (ada hubungan antara sikap dengan kepatuhan ibu membawa balita ke Posyandu Danau Indah Punggur 1 tahun 2020). Analisis keeratan hubungan dua variabel didapat $\mathrm{OR}=2,143$.

7. Hasil uji statistik chi-square didapatkan nilai pvalue $0,029 \leq 0,05$ berarti dapat disimpulkan artinya Ho ditolak dan Ha diterima (ada hubungan antara dukungan 
keluarga dengan kepatuhan ibu membawa balita ke Posyandu Danau Indah Punggur 1 tahun 2020). Analisis keeratan hubungan dua variabel didapat $\mathrm{OR}=1,667$

\section{SARAN}

1. Bagi Tenaga Kesehatan

Lebih meningkatkan kinerja dan pengetahuan petugas kesehatan dan kader sehingga mampu menimbulkan kepercayaan masyarakat terhadap kegiatan Posyandu. Meningkatkan promosi kesehatan pada ibu balita untuk rutin berkunjung ke posyandu setiap bulan sampai anak berumur 5 tahun.

2. Bagi Puskesmas

Diharapkan menciptakan inovasi baru sehingga kegiatan Posyandu lebih menarik minat ibu untuk datang ke Posyandu seperti memberikan penghargaan seperti sertifikat kepada ibu yang patuh membawa balita ke Posyandu. Selain itu Puskesmas melibatkan lintas sektor dalam promosi kesehatan sehingga mampu meningkatkan perhatian masyarakat terhadap kegiatan Posyandu.

3. Bagi Peneliti selanjutnya

Melakukan penelitian lanjutan tentang faktor faktor yang mempengaruhi kepatuhan ibu membawa balita ke Posyandu dengan jumlah sampel yang lebih banyak dan variabel selain tingkat pengetahuan ibu, sikap dan dukungan keluarga serta teknik penelitian yang berbeda sehingga didapatkan gambaran yang lebih baik lagi terhadap faktor apa saja yang mempengaruhi kepatuhan ibu membawa balita ke Posyandu.

\section{DAFTAR PUSTAKA}

Basalamah, U. M., \& Hardaningsih, G. (2016). Pengaruh Growth Faltering Terhadap Kejadian Demam Dan Kejang Demam Pada Anak Pasca Imunisasi Campak. Jurnal Kedokteran Diponegoro, 5(4), 1834-1845.

Brentani, A., Grisi, S. J. F. E., Taniguchi, M. T., Ferrer, A. P. S., de Moraes Bourroul, M. L., \& Fink, G. (2016). Rollout of community-based family health strategy (programa de saude de familia) is associated with large reductions in neonatal mortality in São Paulo, Brazil. SSM - Population Health, 2, 55-61. https://doi.org/10.1016/j.ssmph.2016.01.001

Busri. (2017). Faktor Faktor yang Menyebabkan Rendahnya Peran Ibu Balita ke Posyandu Desa Sumber Datar Wilayah Kerja Puskesmas Keranji Tahun 2016. Jurnal Doppler Universitas Pahlawan Tuanku Tambusai, 1(2), 15-26.

Dharma. (2017). Metodologi Penelitian Keperawatan: Panduan melaksanakan dan Menerapkan Hasil Penelitian (Revisi Tah). Jakarta: Trans Info Media Jakarta. 
Dinas Kesehatan Aceh. (2016). Dinas Kesehatan Aceh (pp. 1-2). pp. 1-2. Retrieved from https://dinkes.acehprov.go.id/news/read/2016/04/01/109/apa-ituposyandu.html

Dinkes, K. B. (2018). Profil kesehatan Kota Batam Tahun 2018. In Profil Kesehatan Kota Batam. Retrieved from file:///C:/Users/User/Downloads/PROFILKESEHATAN-KOTA-BATAM-2018.pdf

Djamil, A. (2017). Faktor-Faktor yang Berhubungan dengan Perilaku Ibu Balita Menimbang Anaknya ke Posyandu. Jurnal Kesehatan, 8(1), 127. https://doi.org/10.26630/jk.v8i1.409

Hilinti. (2018). Gambaram Pengetahuan Masyarakat dalam Pemanfaatan Posyandu di Desa Margo Mulyo Kabupaten Bengkulu Tengah, Agustus 2017. Journal of Midwifery, 6(1), 44-51.

Kemenkes. (2018). Data dan Informasi Profil Kesehatan Indonesia. Jakarta.

Kementrian Kesehatan Jakarta. (2018). Survey Demografi dan Kesehatan Indonesia. In Survei Demografi dan Kesehatan Indonesia. https://doi.org/0910383107 [pii]/r10.1073/pnas.0910383107

Kementrian Kesehatan RI. (2014). Buku Panduan Kader Posyandu. Jakarta: Kementrian Kesehatan RI.

Noeralim, Laenggeng, Y. (2016). Factors Related To Visit Frequency of Infansts ' Mothers on. Faktor Fakktor Yang Berhubungan Dengan Keaktifan Kunjungan Balita Ke Posyandu Di Desa Watuawu Kecamatan Lage Kabupaten Poso, 323333.

Rahmatika, S. D. (n.d.). Hubungan PekerjaanbuBU Dan Dukungan Keluarga Dengan Partisipasi Penimbangan Balita Ke Posyandu Wilayah Kerja Puskesmas Karangmojo I Kabupaten Gunung Kidul.9-17.

Rika. (2016). HUBUNGAN ANTARA PENGETAHUAN DAN PERILAKU PENCEGAHAN GASTRITIS PADA MAHASISWA JURUSAN KEPERAWATAN Skripsi. $1-10$.

Rusmania, N. (2015). Kepatuhan Pasien Rawat Inap Diet Diabetes Mellitus Berdasarakan Teori Kepatuhan Niven. Jurnal Administrasi Kesehatan Indonesia Volume 3 Nomor 1 Januari-Juni 2015, volume 3, 10-17. https://doi.org/10.1145/3132847.3132886

Siagian, R. A. (2018). HUBUNGAN ANTARA DUKUNGAN KELUARGA 
DENGAN KONSEP DIRI PADA REMAJA DI SMP PAB 8 SAMPALI. Fakultas Psikologi Universitas Medan Area.

Simbolon. (2015). APLIKASI THEORY OF REASONED ACTION UNTUK MEMPREDIKSI PERILAKU KONSUMEN DALAM PEMBELIAN SEPEDA MOTOR YAMAHA VIXION. 15(10), 8509-8515.

Subandi, H., \& Fadhil, M. I. I. (2018). Analisis Faktor-Faktor Yang Mempengaruhi Kepatuhan Pajak Bendahara Desa Di Kota Batu. Berkala Akuntansi Dan Keuangan Indonesia, 3(1), 1. https://doi.org/10.20473/baki.v3i1.5402

Sujarweni. (2014). Penelitian Keperawatan dengan SPSS (cetakan Pe; Nayla, Ed.). Retrieved from pustaka_baru@yahoo.com

Sukamerta. (2017). Etika Penelitian dan Penulisan Artikel Ilmiah (Dilenkapi Contoh Proses Validasi Karya Ilmiah). Unmas Press, 84. Retrieved from https://www.academia.edu/36804896/Buku_Referensi_ETIKA_PENULISAN_I LMIAH

Susanti, R. N. (2017). Kuesioner Pengaruh Karakteristik Ibu, Jarak, Dukungan Keluarga Dan Dukungan Petugas Kesehatan Terhadap Kelengkapan Imunisasi Dasar Pada Bayi Diwilayah Kerja Puskesmas Tanah Tinggi Kecamatan Binjai Timur Kota Binjai Tahun 2017.

Susilowati. (2017). Bidan Prada: Jurnal Ilmiah Kebidanan, Vol. 8 No. 2 Edisi Desember 2017,. Kepatuhan Ibu Balita Berkunjung Ke Posyandu Di Desa Karangrejo Kecamatan Wonosalam Kabupaten Demak, 8, 80-88. Retrieved from esusilowati27@gmail.com

Tjetjep, D. (2017). Profile Kesehatan Propinsi KEPRI tahun 2017.

Umairoh. (2014). Analisis Faktor yang Mempengaruhi Perilaku Perineal Hygiene pada Remaja Putri Berbasis Precede Proceed Model di SMPN 45 Surabaya. Retrieved from liestira@yahoo.co.id

UNICEF. (2019). Levels \& Trends in Child Mortality: Report 2013-Estimates developed by the UN Inter-agency Group for Child Mortality Estimation. Unicef/Who/Wb/Un, 1-32. https://doi.org/10.1371/journal.pone.0144443

Wahyuningsih, I. R. (2018). Determinan Perilaku Kader Dalam Penerapan Program Pendampingan Ibu Hamil Di Puskesmas Plupuh I Sragen. Gaster| Jurnal Ilmu Kesehatan, 16(2), 148. https://doi.org/10.30787/gaster.v16i2.299 
Walls, E. (2019). Assessing for faltering growth in infants and children. British Journal of Nursing, 28(17), 1112-1114. https://doi.org/10.12968/bjon.2019.28.17.1112

Wandikbo, P. (2018). Pengetahuan Dan Dukungan Keluarga Tentang Imunisasi Pada Balita di Puskesmas Asologaima Kabupaten Jayawijaya. Retrieved from file:///C:/Users/User/Downloads/JURNAL DUKUNGAN KELUARGA, PENGETAHUAN JAYAWIJAYA.pd 